\title{
Economic Incentives as a Tool for Reducing Deforestation in Egba Division of Ogun State, Nigeria
}

\author{
ATANDA, TA \\ Federal University of Agriculture College of Environmental Resources Mgt. Dept. of Forestry and Wildlife Mgt.PMB.2240, Abeokuta, \\ Ogun State, Nigeria. Email: Atandatoyeeb@gmail.com
}

\begin{abstract}
The study was carried out to assess economic incentives as a tool for reducing deforestation in Egba Division of Ogun State. Data collected from 120 respondents were analysed using descriptive statistics and logistic regression model while Likert scale was used to rate the mean score of anthropogenic factors promoting deforestation and economic incentives used for reducing deforestation. The result showed that majority $(68.3 \%)$ of the respondents were male with $(32.7 \%)$ female. On age, $41-50$ years $(63.3 \%)$ recorded the highest. Educationally, $(51.7 \%)$ had primary education, $(31.7 \%)$ no formal education, $(15.8 \%)$ with secondary education while $(0.8 \%)$ had tertiary education. On income, major income recorded a mean of $\mathrm{N} 29,066$ while minor income recorded a mean of $\mathrm{N} 13,600$. The anthropogenic factors identified were setting forest ablaze, expanded agricultural activities, low literacy level, rising timber industry, rising population and poverty. The economic incentives identified include provision of subsidies for forest crops, improved taxation system on exploited forest logs, acquisition of well monitored license permit by hunters, alternative employment opportunities, provision of credit and selective ban on exportation of round logs. Logit regression results identified socioeconomic factors on incentives, with only education as the statistically significant variable at $(\mathrm{p}<0.05)$. Conclusively, Economic incentives can be an effective tool for reducing deforestation if properly monitored and implemented. Thus, deforestation activities cannot be totally eradicated but adequate implementation of forest policy in terms of effective policing of the forest can reduce it to the barest minimum.
\end{abstract}

\section{DOI: https://dx.doi.org/10.4314/jasem.v22i10.27}

Copyright: Copyright $(92018$ Atanda. This is an open access article distributed under the Creative Commons Attribution License (CCL), which permits unrestricted use, distribution, and reproduction in any medium, provided the original work is properly cited.

Dates: Received: 10 September 2018; Revised: 24 October 2018; Accepted 29 October 2018

KEYWORDS: Economic incentive, Tool, Deforestation, Egba Division

Deforestation is the removal of a forest or stand of trees where the land is there after converted to a nonforest use (Van Kooten and Bulte, 2000). Deforestation includes not only the conversion to nonforest, but also degradation that reduces forest quality, the density and structure of the trees, the ecological services supplied, the biomass of plants and animals, the species diversity and the genetic diversity (Bauman, 2006). The social and economic impact of deforestation cannot be overemphasized. The transformation of forested lands by human actions represents one of the great forces in global environmental change and one of the great drivers of biodiversity loss (Mbwambo, 2000). In Sub-Saharan Africa which includes Nigeria, many household depend on forest for fuel-wood, which is responsible for more than $75 \%$ of all energy consumed in the country annually .The accelerating nature of deforestation is also threatening the sustained resources base of the forest raw materials and causing various economic and environmental hazards. Economic incentives refer to specific inducements designed and implemented to influence government bodies, business, non-governmental organisations, or local people to sustainably and responsibly conserve, utilize and manage environmental resources (Emerton, 2000). This underscores the importance of this study with the following objectives: To describe the socio economic profile of the respondents, to identify anthropogenic factors promoting deforestation, to determine the effect of socio economic factors on incentives and to identify economic incentives used for reducing deforestation.

\section{MATERIALS AND METHODS}

The Study Area: Egba division is one of the four geographical zones Ogun state is divided into along with Yewa, Ijebu and Remo. Ogun State is located within latitude $7^{0} \mathrm{~N}$ and $7^{0} 5 / \mathrm{N}$ and longitude $3^{0} 3 / \mathrm{E}$ and $3^{\circ} 37 / \mathrm{W}$ (Figure 1). It covers a total land area of $16,409.26 \mathrm{~km}^{2}$. The State is bounded in the north by Oyo and Osun States, in the east by Ondo State, in the south by Lagos State and Atlantic Ocean. The State also shares an international border with Benin Republic. It has Abeokuta as its capital. The population of Ogun State according to a recent 
estimate from the National population commission is $3,751,140$ - male 1,864,907; female 1,886,233. Agriculture is the mainstay of the State's economy and employs a large per cent of the population (NBS, 2006). The soils in the area are dominated by clayey loam developed on underlying granite. There are also laterite soils. Egba area has extensive free forest areas with two gazetted forest reserves of $61.19 \mathrm{~km}^{2}$ land area. Major timber crops include Tectona grandis and Gmelina arborea with other indigenous species from the free areas (Ogun State today, 2001).

Data Collection: The instrument of data collection was a semi-structured questionnaire. The questionnaire was administered with interview guide to the respondents. A non-probability quota sampling procedure was used as an ideal sampling technique for survey of Egba division of Ogun state. A predetermined sampling frame of 120 respondents was selected across the six (6) local governments in the zone. Quota sampling technique was used to select 120 respondents across the six (6) local governments in the zone and in each local government 20 respondents was selected. The distribution of the respondents is presented in Table 1.

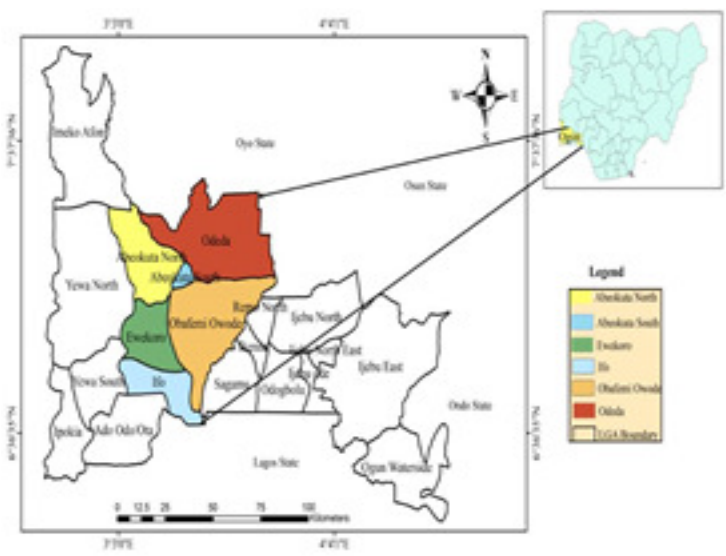

Fig 1: Map of Ogun State Showing the Study area

Table 1: Sampling plan of the study area

\begin{tabular}{|c|c|c|}
\hline $\mathrm{S} / \mathrm{N}$ & Location & No of Respondents \\
\hline 1. & $\begin{array}{l}\text { Odsda local government } \\
\text { Agbede and Alabata village }\end{array}$ & 20 \\
\hline 2. & $\begin{array}{l}\text { Ifo local government } \\
\text { Pakoto, Onihale and Alaja villages }\end{array}$ & 20 \\
\hline 3. & $\begin{array}{l}\text { Ewekoro local government } \\
\text { Arigbajo and Papalanto }\end{array}$ & 20 \\
\hline 4. & $\begin{array}{l}\text { Obafemi-owode local govemment } \\
\text { Sowumi and Osoba village }\end{array}$ & 20 \\
\hline 5. & $\begin{array}{l}\text { Abeokuta-south local government } \\
\text { Ipa-orogbo and Ogunmalin village }\end{array}$ & 20 \\
\hline 6. & $\begin{array}{l}\text { Abeokuta-north local govemment } \\
\text { Ibara-orile, Imala -oko and Olorunda villages }\end{array}$ & 20 \\
\hline & Total & 120 \\
\hline
\end{tabular}

Data analysis: Data collected were analysed using descriptive statistics and logistic regression model. Descriptive statistics such as table, frequency distribution and percentages was used to analyze socio-economic characteristics of respondents, anthropogenic factors promoting deforestation, and economic incentives used for reducing deforestation. Likert scale was used to rate the mean score of anthropogenic factors promoting deforestation and economic incentives used for reducing deforestation. Logit regression model was used to analyze effects of socio-economic factors on incentives.

\section{RESULTS AND DISCUSSION}

Socio-economic profile of respondents: Table 2 showed socio-economic characteristics of the respondents. Gender distributions showed that majority $(68.3 \%)$ of the respondents were male while $(32.7 \%)$ were female. Marital status showed Majority $(84.2 \%)$ of the respondents were married, (7.5\%) single, $(5 \%)$ divorce and $(3.3 \%)$ widow. On family size, Majority of the respondents $(67.9 \%)$ had family size of $1-5$. On age, $41-50$ years $(63.3 \%)$ recorded the highest. The mean age of the respondents was 43 years. Educationally, (51.7\%) had primary education, $(31.7 \%)$ no formal education, $(15.8 \%)$ with secondary education while $(0.8 \%)$ had tertiary education. On occupation, Majority, (64.2\%) of the respondents were involved in farming as major occupation. On income, major income recorded a mean of $\$ 29,066$ while minor income recorded a mean of $\$ 13,600$.

Anthropogenic factors promoting deforestation: A summary of anthropogenic factors promoting deforestation is shown in table 3 . The anthropogenic factors identified were setting forest ablaze, expanded agricultural activities, low literacy level, rising timber industry, rising population and poverty. The economic incentives identified include provision of subsidies for forest crops, improved taxation system on exploited forest $\operatorname{logs}$, acquisition of well monitored license permit by hunters, alternative employment opportunities, provision of credit and selective ban on exportation of round logs.

Logistic Regression analysis: Table 4 shows logistic regression result of the effect of socio-economic factors on incentives. The analysis of result shown in table 4 shows only education as the statistically significant variable at $(\mathrm{p}<0.05)$. The implication of the above analysis is that those respondents in the study area with higher educational attainment are likely to respond better in the use of economic incentives and will not involve more cost in deforestation activities in the study area. 
Table 2: Socio- economic characteristics of respondents

\begin{tabular}{llll}
\hline Variables & Frequency & Percentage & Mean/Mode \\
\hline Age & & & \\
$\leq 20$ & 1 & 0.8 & \\
$21-30$ & 19 & 15.8 & \\
$31-40$ & 9 & 7.5 & \\
$41-50$ & 76 & 63.3 & 43 years \\
$>51$ & 15 & 12.5 & \\
Total & 120 & 100.0 & \\
Gender & & & \\
Male & 82 & 68.3 & Male \\
Female & 38 & 31.7 & \\
Total & 120 & 100.0 & \\
Level of Education & & & \\
Primary Education & 62 & 51.7 & Primary \\
Secondary & 19 & 15.8 & \\
Tertiary & 1 & 0.8 & \\
No formal education & 38 & 31.7 & \\
Total & 120 & 100.0 & \\
Family size & & & \\
1-5 & 85 & 67.95 & 4 \\
6-10 & 35 & 32.1 & \\
Total & 120 & 100.0 & \\
Marital status & & & \\
Single & 9 & 7.5 & \\
Married & 101 & 84.2 & Married \\
Divorced & 6 & 5.0 & \\
Widow & 4 & 3.3 & \\
Total & 120 & 100.0 & \\
Major occupation & & & \\
Civil servant & 10 & 8.3 & \\
Farmer & 77 & 64.2 & \\
Trader & 27 & 22.5 & \\
Driver & 1 & 8 & \\
Others & 5 & 4.2 & \\
Total & 120 & & \\
Major income (N) & & & \\
10,000-20,000 & 16 & 13.3 & \\
20,000-30,000 & 70 & 58.3 & \\
30,000-40,000 & 34 & 28.4 & \\
Total & 120 & 100.0 & \\
Minor income ( $)$ & & & \\
$0-10,000$ & & 32.5 & \\
\hline
\end{tabular}

\begin{tabular}{llll}
\hline $10,000-20,000$ & 72 & 60.0 & 13,600 \\
$20,000-30,000$ & 9 & 7.5 & \\
Total & 120 & 100.0 & \\
\hline
\end{tabular}

Source: Field survey, 2017

Table 3: Anthropogenic factors promoting Deforestation

\begin{tabular}{|c|c|c|c|c|}
\hline & VARIABLES & SD & MEAN & Inference \\
\hline 1 & $\begin{array}{l}\text { Setting forest ablaze using wild fire will } \\
\text { promote deforestation }\end{array}$ & 0.698 & 4.53 & Strongly Agreed \\
\hline 2 & $\begin{array}{l}\text { Expanded agricultural activities will } \\
\text { promote deforestation }\end{array}$ & 0.475 & 4.10 & Strongly Agreed \\
\hline 3 & $\begin{array}{l}\text { Low literacy level among the populace } \\
\text { will promote deforestation }\end{array}$ & 0.902 & 4.40 & Strongly Agreed \\
\hline 4 & $\begin{array}{l}\text { Rising population and food demand will } \\
\text { promote deforestation }\end{array}$ & 1.278 & 3.88 & Agreed \\
\hline 5 & Poverty will promote defores tation & 0.640 & 4.29 & Strongly Agreed \\
\hline 6 & $\begin{array}{l}\text { Rising timber industry will promote } \\
\text { deforestation }\end{array}$ & 1.001 & 4.13 & Strongly Agreed \\
\hline
\end{tabular}

Source: Field survey, 2017

Table 4: Effect of socio-economic factors on incentives

\begin{tabular}{llll}
\hline Variables & Coefficient & $\mathrm{Z}$ & Marginal effect \\
\hline Marital status & 3543101 & 0.71 & .0606226 \\
Family size & 9737316 & 1.79 & .1784084 \\
Education & 1.349578 & $2.47^{*}$ & .2685691 \\
Tribe & .7087876 & 1.21 & .1364756 \\
Constant & -1.134198 & -1.87 & \\
y = Pr (gender) (predict) $=78135165 ;$ Significant at 5\%; Source: \\
\multicolumn{4}{c}{ Field survey, 2017 }
\end{tabular}

Economic incentives used for reducing deforestation: Table 5 shows the economic incentives that can be used for reducing deforestation in the study area. The economic incentives identified include provision of subsidies for forest crops, improved taxation system on exploited forest logs, acquisition of well monitored license permit by hunters, alternative employment opportunities, provision of credit and selective ban on exportation of round logs.

Table 5: Economic incentives used for reducing Deforestation

\begin{tabular}{|c|c|c|c|c|}
\hline & VARIABLES & SD & MEAN & Inference \\
\hline 1 & $\begin{array}{l}\text { Improved taxation system on exploited logs from the forest will reduce } \\
\text { deforestation }\end{array}$ & 0.797 & 4.36 & Strongly Agreed \\
\hline 2 & Provision of subsidies for forest crops will reduce deforestation & 0.582 & 4.78 & Strongly Agreed \\
\hline 3 & $\begin{array}{l}\text { Well monitored license permit before exploitation of trees will reduce } \\
\text { deforestation }\end{array}$ & 0.536 & 4.63 & Strongly Agreed \\
\hline 4 & Alternative employment opportunities will reduce deforestation & 1.146 & 3.88 & Agreed \\
\hline 5 & $\begin{array}{l}\text { Provision of credit such as loan facilities for forest entrepreneurs will } \\
\text { reduce deforestation }\end{array}$ & 0.706 & 4.35 & Strongly Agreed \\
\hline 6 & Selective ban on exportation of round logs will reduce deforestation & 0.357 & 4.88 & Strongly Agreed \\
\hline 7 & Multiple use of forest land will reduce deforestation & 0.550 & 4.50 & Strongly Agreed \\
\hline 8 & Reduced levy on imported forestry machinery will reduce deforestation & 1.112 & $\mathbf{2 . 8 8}$ & Undecided \\
\hline 9 & Tax exemption for forest entrepreneurs will reduce deforestation & 1.464 & 2.34 & Disagreed \\
\hline
\end{tabular}
SOURCE: Field survey, 2017

Conclusion: Economic incentives if properly monitored and implemented can be an efficient tool to reduce deforestation because they are likely to prove the most effective measures for converting over exploitation to sustainable use of biological resources.
Thus, deforestation activities cannot be totally eradicated due to increase in human population on daily basis but adequate implementation of forest policy in terms of effective policing of the forest can reduce it to the barest minimum. 


\section{REFERENCES}

Baumann, P (2006). Forest - poverty linkages in West and Central Asia: The outlook from a sustainable livelihoods perspective. FAO LSP WP 34. Access to Natural Resources Sub Programme. 4pp.

Emerton, L (2000). Using economic incentives for biodiversity conservation, economics and biodiversity programme. World Conservation Union, Switzerland. p: 299.

Giliba, RA; Boon, EK; Kayombo, CJ; Chirenje, LI; Musamba, EB (2011). The influence of socioeconomic factors on deforestation: a case study of the Bereku forest reserve in Tanzania. J Biodivers 2: 31-39.

Mbwambo, JS (2000). The role of local knowledge and organization in sustainable conservation of biodiversity: A case study of Udzungwa
Mountains, Tanzania. Dissertation for the award of MSc Degree at Sokoine University of Agriculture, Morogoro, Tanzania. 126pp

Mendoza, CC (2006). Factors influencing participation in environmental stewardship programs: A case study of the agricultural and forestry sectors in Louisiana. PhD Thesis, Louisiana State University, USA. p: 10-25.

NBS (2006). National Bureau of Statistics Nigerian Core Welfare Indicators Study. Abuja, Nigeria.

Ogun State Today (2001). An appraisal of the Gateway State at 25: 1976- 2001. Ogun State Ministry of information, Abeokuta, Ogun State, Nigeria.

Van Kooten, GC; Bulte, EH (2000). The economics of nature: managing biological assets. 